\title{
Structural Characterization of Functional Ingredient Levan Synthesized by Bacillus siamensis Isolated from Traditional Fermented Food in Thailand
}

\author{
Nattapong Thakham, ${ }^{1,2}$ Supphasin Thaweesak, ${ }^{2}$ Nuttinee Teerakulkittipong, ${ }^{3}$ \\ Natthiwut Traiosot, ${ }^{4}$ Autaipohn Kaikaew, ${ }^{4,5}$ Gary Antonio Lirio, ${ }^{6}$ and Witawat Jangiam $\left(^{2,4}\right.$ \\ ${ }^{1}$ Department of Chemical Engineering, National Chung Hsing University, Xingda Road, Taichung City 402, Taiwan \\ ${ }^{2}$ Department of Chemical Engineering, Faculty of Engineering, Burapha University, Saensook, Maung, Chonburi 20131, Thailand \\ ${ }^{3}$ Faculty of Pharmaceutical Sciences, Burapha University, Saensook, Maung, Chonburi 20131, Thailand \\ ${ }^{4}$ Bioengineering Program, Faculty of Engineering, Burapha University, Saensook, Maung, Chonburi 20131, Thailand \\ ${ }^{5}$ College of Research Methodology and Cognitive Science, Burapha University, Saensook, Maung, Chonburi 20131, Thailand \\ ${ }^{6}$ Institute for Science and Technology Research, Center for Life Sciences Research, Polytechnic University of the Philippines, \\ Manila 1008, Philippines \\ Correspondence should be addressed to Witawat Jangiam; witawat@eng.buu.ac.th
}

Received 15 January 2020; Revised 15 May 2020; Accepted 22 May 2020; Published 6 June 2020

Academic Editor: Carl J. Schaschke

Copyright (c) 2020 Nattapong Thakham et al. This is an open access article distributed under the Creative Commons Attribution License, which permits unrestricted use, distribution, and reproduction in any medium, provided the original work is properly cited.

\begin{abstract}
The rising global population continues to threaten the world's food security. The discovery of new technologies to produce food of nutritional and functional properties is urgently needed. One beneficial food to humans of known nutritional value is the prebiotic levan. To address the problem, the present work is aimed at isolating levansucrase enzyme-producing microorganisms from traditional fermented food in Thailand. Bacterial colony morphology was observed for mucoidal consistency on culture plates. Isolated colonies were characterized morphologically by gram staining methods. Dinitrosalicylic acid (DNS) and thin-layer chromatography (TLC) reported the highest microbial enzyme activity of $8.51 \mathrm{IU} / \mathrm{ml}$ at 12 hours via hydrolysis and frutotransferase activities. Structural characterization of levan via Fourier-transform infrared spectroscopy (FTIR) and ${ }^{1} \mathrm{H}$ and ${ }^{13} \mathrm{C}$ nuclear magnetic resonance (NMR) spectroscopy showed $\beta$-(2,6)-fructofuranose linkages. The highest enzyme activity was exhibited by bacterium B-6 identified as Bacillus siamensis NR 11274.1 based on the 16s rDNA gene sequence analyses. Thus, the isolated bacterium from the traditional food was confirmed to produce levansucrase enzyme of high industrial importance for the synthesis of levan as a functional food.
\end{abstract}

\section{Introduction}

Exopolysaccharides (EPSs) have been widely utilized in the food industries and dairy products as functional ingredients due to their multifunctional properties as viscosifying [1], stabilizing [2], emulsifying [3], gelling [4], and waterbinding agents [5]. EPSs also were found to exhibit various health benefits, for example, in the reduction of cholesterol levels [6], inhibition of biofilm formation by pathogenic organisms [7], and as prebiotics for promoting the growth of microbiota in the human gastrointestinal tract [8].
Dietary prebiotics is a selectively fermented ingredient that stimulates specific changes in the composition and activity of the gastrointestinal microbiota and is known for many beneficial effects to the host [9]. The consumption of prebiotics has been reported to improve health by metabolizing the products by the intestinal microbiota in the likes of Bifidobacteria and Lactobacilli species [10, 11]. These microbiota consume the EPSs to synthesize several products such as short-chain fatty acids [12], lactic acid, and peptides [13]. The metabolized products are found to possess various beneficial effects in the intestinal environment, such as in 
maintaining normal luminal $\mathrm{pH}$ in the colon, in growth stimulation of the lactic microflora in the human gastrointestinal tract, and in the production of antimicrobials against pathogens $[14,15][16]$. It is indeed clear that the consumption of prebiotics is advantageous to human health, specifically in achieving gastrointestinal homeostasis. However, known adverse effects due to excessive consumption of prebiotics have been documented, causing flatulence, abdominal disorders, and diarrhea as these products upregulate the growth and metabolism of indigenous gut microbiota [17]. Thus, several oligo- and polysaccharides for nutrition have been studied for their prebiotic potentials [18]. The recommended intake of prebiotics to confer health benefits should be followed as in inulin (8-40 g/day, 15-64 days) or fructooligosaccharides (FOSs) (4-12.5 g/day, 8-12 days) [15, 19]; both are polysaccharides found in fruits and vegetables.

Fructooligosaccharides (FOSs), fructans, $\beta$-(2-1)-inulin type, and $\beta$-(2-6)-levan type are the types of prebiotics that have been reported to be valuable in maintaining intestinal health [20]. Inulin and levan, for instance, are comparable to the prebiotic properties of fructans, which in some studies revealed that levan significantly increased the total number of microbiota in the intestine of animals [21] [22, 23]. Furthermore, numerous studies have reported other properties of levan including antitumor activity $[24,25]$, anti-irritant [26], antioxidant, and anti-inflammatory properties [27]; and promotion of blood clotting [28]. Moreover, levan as a nanoparticle has gained prominence for enhancing the delivery of peptides and other protein-based drugs $[29,30]$.

Levan structure includes the D-fructofuranosyl residues joined by $\beta-(2-6)$ linkages as the main chain with some $\beta$ (2-1)-linked branched chains [31]. The degree of polymerization (DP) is estimated to be over 100,000 DP [21]. This polysaccharide is usually synthesized by levansucrase enzyme (EC 2.4.1.10), sucrose-6-fructosyltransferase, or fructosyltransferase belonging to glycoside hydrolase family 68 (GH68) produced by some strains of bacteria $[32,33]$. The mechanism of levansucrases acts on catalyzing sucrose by fructosyltransferase reaction and by hydrolysis to form levan $[34,35]$. The active site of levansucrases consists of 2 subsites which are -1 subside to be of high affinity for fructose residue binding and +1 subside, which is able to accommodate glucose and fructose residues. First, sucrose occupies the -1 subside covalent fructosyl enzyme, and sucrose is then hydrolyzed, releasing glucose. The process is then followed by another fructose residue on sucrose, attracting at the +1 subsite to bind the fructosyl enzyme by the fructosyltransferase reaction leading to synthesized $\beta$ - $(2,6)$-linked oligofructans, which leads to the formation and elongation of levan [20]. Levansucrase has been known to be synthesized by several microorganisms, including the gut microbiota, for example, Lactobacillus johnsonii, Lactobacillus gasseri, Bacillus subtilis [36], Aerobacter levanicum, and Streptococcus salivarius $[28,33]$. However, limited attempts were made to determine the production of levansucrase enzymes from bacteria present in traditional foods, such as in fermented soybeans [37].

Thus, the present study reports on the screening of isolated microorganisms from a traditionally fermented food

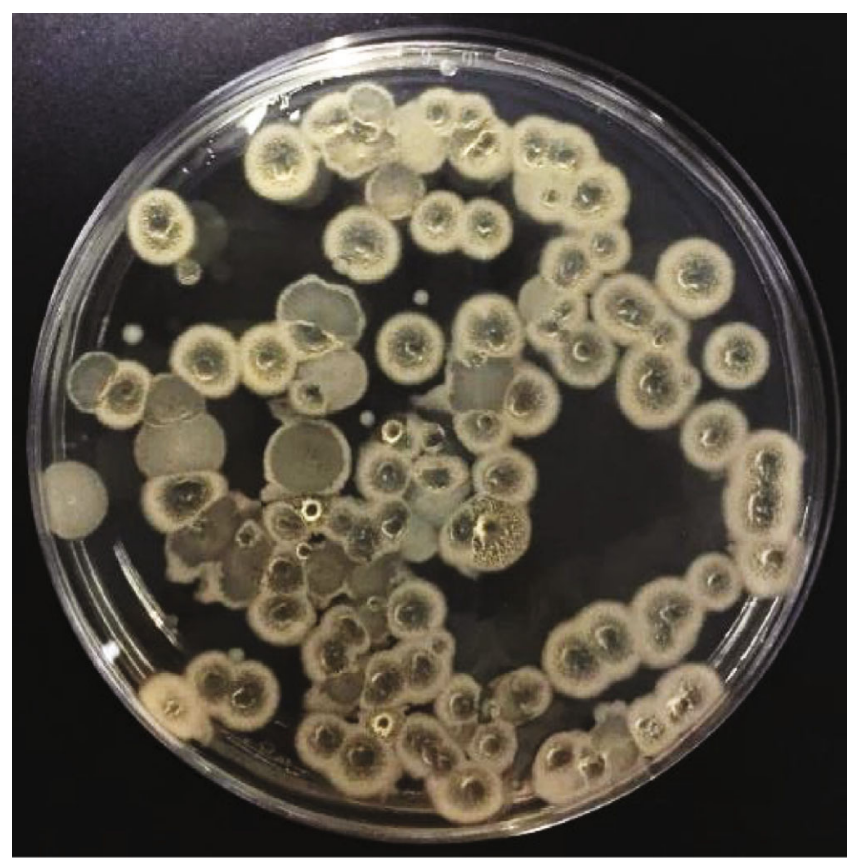

FIgURE 1: Mixed-growth cultures of microorganisms from fermented soybean. Isolates exhibited mucoidal colonies on agar medium containing $20 \% \mathrm{w} / \mathrm{v}$ of sucrose incubated at $37^{\circ} \mathrm{C}$ for 24 hours.

in Thailand for levansucrase enzyme production and unravels their potential for the synthesis of levan as a functional food.

\section{Materials and Methods}

2.1. Isolation and Identification of Levansucrase EnzymeProducing Bacteria. The samples of the locally fermented soybean (Thua-nao) were collected from the northeastern region of Thailand (Wiang Haeng District, in Chiang Mai Province, 50350, Thailand) and were processed for the isolation of levansucrase enzyme-producing bacteria. The cultivation and isolation of bacteria were performed following serial dilution and plate methods. The suspensions were plated onto the selective medium containing $200.0 \mathrm{~g} / \mathrm{l}$ sucrose, $5.0 \mathrm{~g} / \mathrm{l}$ yeast extract, $10.0 \mathrm{~g} / \mathrm{l}$ tryptone, $2.5 \mathrm{~g} / \mathrm{K} \mathrm{K}_{2} \mathrm{HPO}_{4}$, and $15.0 \mathrm{~g} / \mathrm{l}$ agar, incubated at $37^{\circ} \mathrm{C}$ for 24 hours. The mixed culture plates were observed for colonies exhibiting mucoidal consistency and were subcultured on fresh nutrient agar (NA) plates. Gram stain method [38] was performed to characterize the isolates morphologically and to obtain data that support the identification of bacteria from the genus to species level.

The highest levansucrase enzyme-producing isolate was identified further by the molecular techniques and through analysis of the partial $16 \mathrm{~s}$ rDNA gene sequences. The genomic DNA was extracted from freshly grown cells in NA plates for 24 hours [39]. The 16s rDNA gene sequences were amplified by PCR with the universal primers $27 \mathrm{~F}$ ( $5^{\prime}$-AGAGTTTGA TCATGGCTCAG- $3^{\prime}$ ) and 1492R (5'TACGGTTACCTTGT TACGACTT- $3^{\prime}$ ), subsequently purified by the DNeasy Tissue Kit (Qiagen, Germany), sequenced, and further analyzed [40]. 
TABLE 1: Morphology and gram stain technique classification of the 9 bacterial isolates grown on solid agar medium containing $20 \%(w / v)$ of sucrose.

\begin{tabular}{|c|c|c|c|c|c|c|c|}
\hline \multirow{2}{*}{ Isolate code } & \multicolumn{5}{|c|}{ Colony morphology } & \multicolumn{2}{|c|}{ Cell type } \\
\hline & Size & Shape & Opacity & Margin & Surface & Gram & Shape \\
\hline B-1 & Large & Irregular & Opaque & Undulate & Rough & + & Bacilli \\
\hline B-2 & Large & Irregular & Opaque & Undulate & Wrinkled & + & Bacilli \\
\hline B-3 & Large & Irregular & Translucent & Undulate & Rough & + & Bacilli \\
\hline B-4 & Large & Round & Translucent & Entire & Wrinkled & + & Bacilli \\
\hline B-5 & Large & Round & Opaque & Entire & Wrinkled & + & Bacilli \\
\hline B-6 & Large & Round & Transparent & Entire & Smooth & + & Bacilli \\
\hline B-7 & Large & Round & Translucent & Entire & Smooth & + & Bacilli \\
\hline B-8 & Large & Round & Translucent & Entire & Rough & + & Bacilli \\
\hline B-9 & Small & Round & Translucent & Entire & Smooth & - & Cocci \\
\hline
\end{tabular}

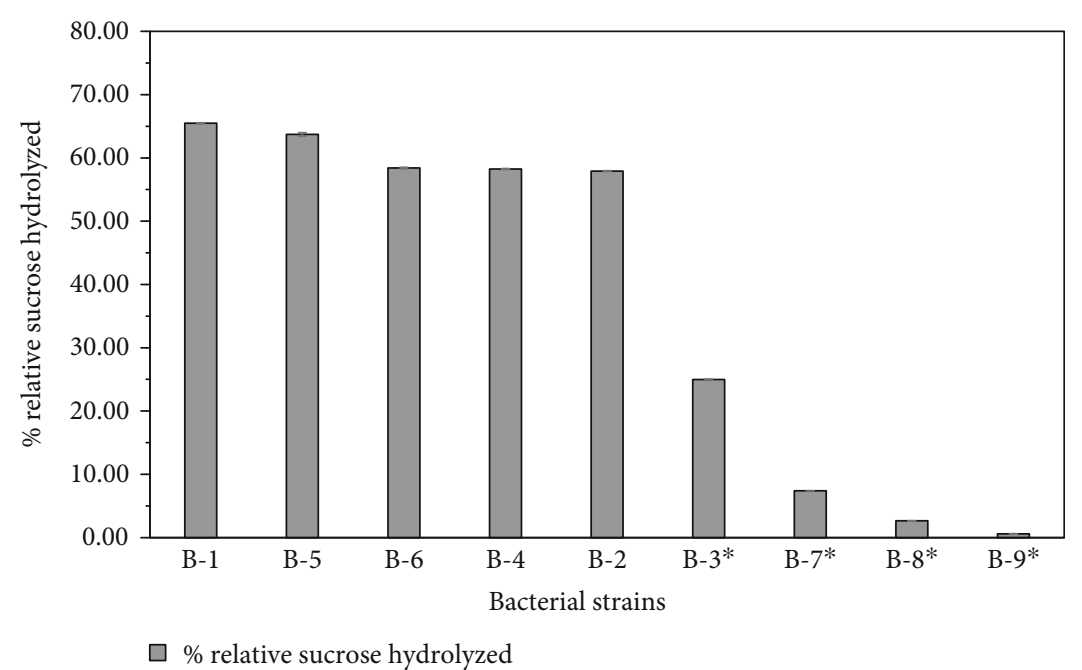

Figure 2: Results of the sucrose hydrolysis of the nine bacterial strains isolated from fermented soybean. The relative activity refers to the maximum activity. *Statistically significant difference with B-1.

PCR condition was as follows: $94^{\circ} \mathrm{C}$ for $3 \mathrm{~min}, 30$ cycles of $94^{\circ} \mathrm{C}$ for $60 \mathrm{~s}, 55^{\circ} \mathrm{C}$ for $60 \mathrm{~s}$, and $72^{\circ} \mathrm{C}$ for $2 \mathrm{~min}$ with a final extension at $72^{\circ} \mathrm{C}$ for $3 \mathrm{~min}$. The sequence processes including the direct sequencing of $16 \mathrm{~s}$ rDNA were performed by the Biodiversity Research Centre (BRC), Thailand Institute of Scientific and Technological Research (TISTR) (shown in Supplementary Figure 1). The partial 16s rDNA sequence was entered in the BLAST webpages of the National Center for Biotechnology Information (NCBI). Multiple sequence alignment was performed with CLUSTAL X (version 1.83) [41]. Alignment gaps and unidentified bases were edited and eliminated. The neighbor-joining tree was constructed by bootstrap analysis set to 10,000 replicates and calculated using the Kimura two-parameter method [42] with MEGA version 10 software.

\subsection{Levansucrase Activity Assay}

2.2.1. Production of Levansucrase Enzyme from Isolates. One loopful of the colony from the 24-hour freshly grown cultures from each isolate was inoculated into $3 \mathrm{ml}$ of broth medium containing sucrose $50.0 \mathrm{~g} / \mathrm{l}$, tryptone $10 \mathrm{~g} / \mathrm{l}, \mathrm{NaCl} 5.0 \mathrm{~g} / \mathrm{l}$, and yeast extract $5.0 \mathrm{~g} / \mathrm{l}, \mathrm{pH} 7.4$, in test tubes and cultivated at $37^{\circ} \mathrm{C}$ for 24 hours in a rotary shaker set at $200 \mathrm{rpm} \mathrm{[43].}$ After incubation, the culture broth was observed for turbidity, and each was standardized by adding a sterile fresh broth medium to match $0.5 \mathrm{McFarland}$ equivalent to the absorbance of 0.08 to 0.1 at $600 \mathrm{~nm}$ spectrophotometrically [43]. The tubes were incubated at the same conditions previously described. Samples were collected after incubation, centrifuged at $9100 \times \mathrm{g}\left(15 \mathrm{~min}, 25^{\circ} \mathrm{C}\right)$, to obtain the supernatant. The supernatants were kept and set aside for evaluation of the transfructosylating activity. The reducing sugars were determined by the DNS method [44].

2.2.2. Enzyme Mechanisms. Cultivation of bacterial isolates was performed in a $250 \mathrm{ml}$ flasks containing $100 \mathrm{ml}$ of fermentation medium (containing sucrose $200.0 \mathrm{~g} / \mathrm{l}, \mathrm{Na}_{2} \mathrm{HPO}_{4}$ $3.5 \mathrm{~g} / \mathrm{l}, \mathrm{NaH}_{2} \mathrm{PO}_{4} 0.8 \mathrm{~g} / \mathrm{l}, \mathrm{MgSO}_{4} 0.2 \mathrm{~g} / \mathrm{l}, \mathrm{NaNO}_{3} 3.5 \mathrm{~g} / \mathrm{l}$, and yeast extract $5.0 \mathrm{~g} / \mathrm{l}$ ), added with $10 \%$ standardized inoculum, and incubated for 24 hours at $37^{\circ} \mathrm{C}$ on a rotary shaker at $200 \mathrm{rpm}$ [43]. Experiments were carried out in triplicate. 


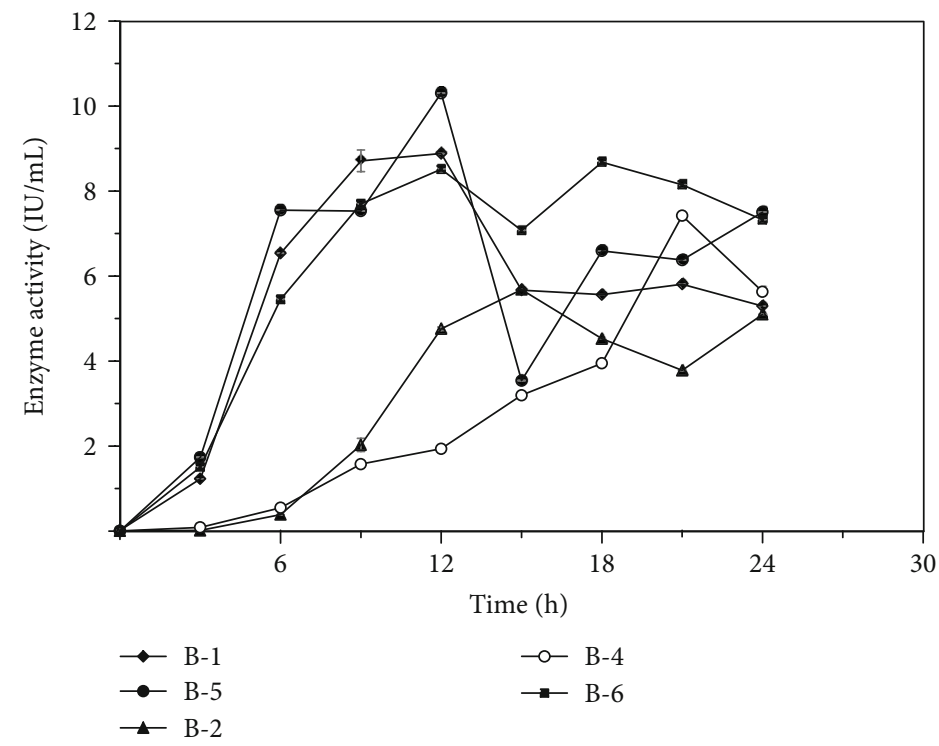

(a)

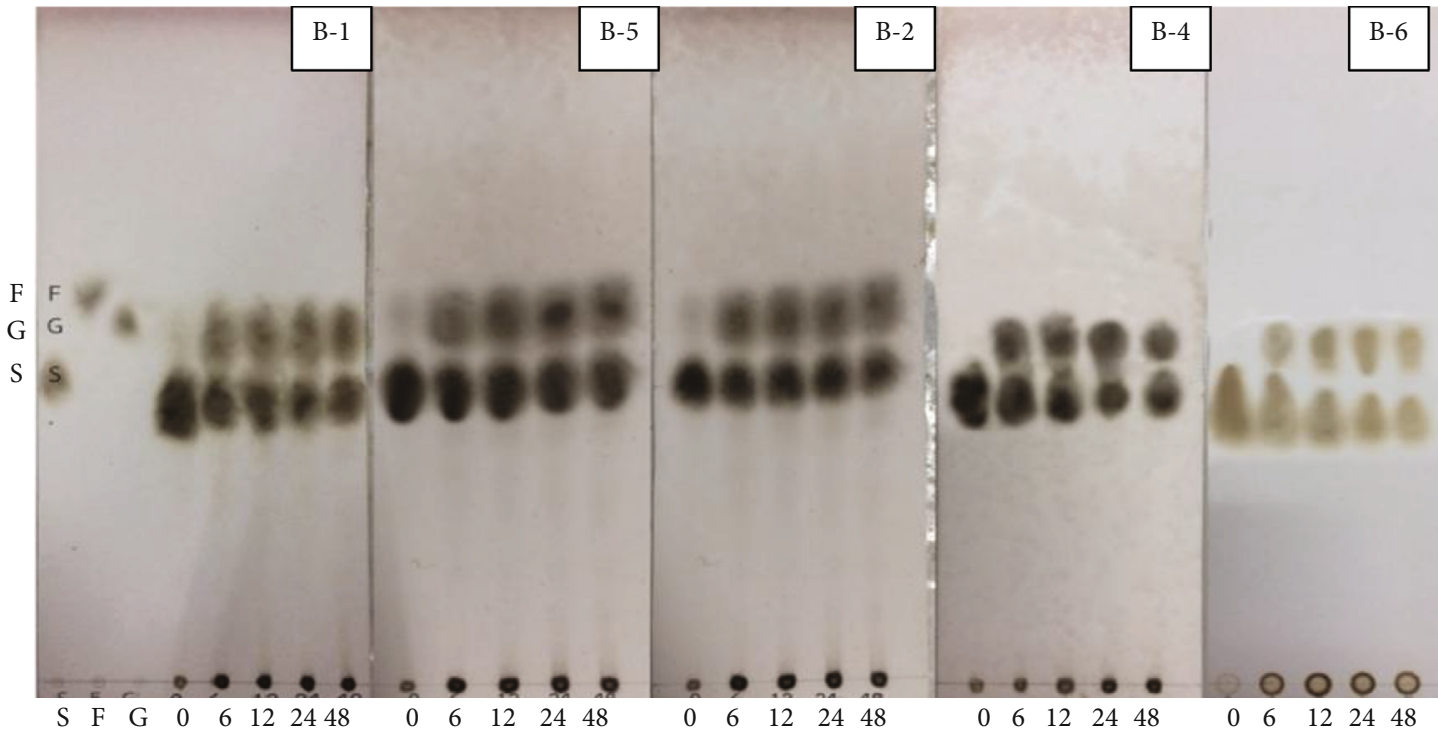

(b)

FIgURE 3: (a) Sucrose-hydrolyzing activity analysis of the extracellular enzyme produced by the five bacterial strains. (b) The TLC chromatogram of analyzed standard solutions: glucose (G), fructose (F), and sucrose (S); stationary phase: silica gel G-60 plates (Merck); mobile phase: chloroform/acetic acid/water (6:7:1 by volume); detection reagent: sulfuric acid and ethanol (1:9 $(v / v))$; volume of sample $10 \mu \mathrm{l}$; the RAF line belongs to sucrose, fructose, and glucose; $0,6,12,24$, and 48 line represents $0,6,12,24$, and 48 h; B-1, B-2, B-4, B-5, and $\mathrm{B}-6$ are bacterial strains.

Sucrose hydrolysis activity was assayed by adding $0.5 \mathrm{ml}$ enzyme obtained from bacterial supernatant to $0.5 \mathrm{ml}$ of $20 \%$ sucrose $(w / v)$ in $20 \mathrm{mM}$ sodium phosphate buffer, $\mathrm{pH} 6.0$, and the reaction mixtures were incubated at $37^{\circ} \mathrm{C}$ for $30 \mathrm{~min}$. The reaction was stopped and the reducing sugars were determined by the DNS method. One unit of the enzyme was defined as the amount of enzyme that produced $1 \mu \mathrm{mol}$ of glucose per minute [45].

2.2.3. Thin-Layer Chromatography (TLC) Analysis. The sugars in the reaction mixtures were analyzed by thin-layer chromatography (TLC) on silica gel G-60 using chlorofor- m/acetic acid/water (6:7:1 by volume) as a mobile phase system. After the layer developed and the mobile phase, evaporation under continuous air for $15 \mathrm{~min}$ was done, and then, the mixtures were kept in an oven set at $115^{\circ} \mathrm{C}$ for $15 \mathrm{~min}$. Spots on the chromatograms were visualized by spraying a mixture of sulfuric acid and ethanol $1: 9(v / v)$ on the TLC plate [46].

\subsection{Isolation, Purification, and Identification of Levan}

2.3.1. Isolation and Purification of Levan. Cultivation was performed in flasks containing $200 \mathrm{ml}$ of fermentation 


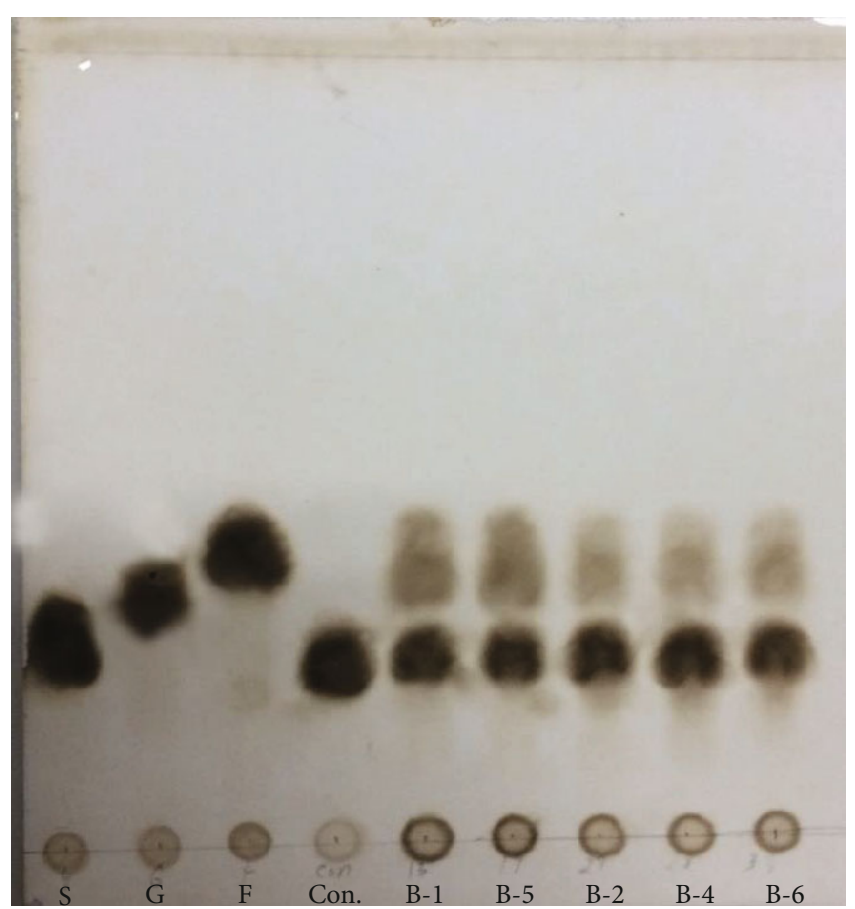

FIgURE 4: The TLC chromatogram of analyzed standard solutions: glucose $(G)$, fructose $(F)$, and sucrose $(S)$; stationary phase: silica gel G-60 plates (Merck); mobile phase: chloroform/acetic acid/water ( $6: 7: 1$ by volume); detection reagent: sulfuric acid and ethanol $(1: 9(v / v))$; volume of sample $10 \mu \mathrm{l}$; the RAF line belongs to sucrose, fructose, and glucose; B-1, B-2, B-4, B-5, and B-6 are bacterial strains.

medium and inoculated with $10 \%$ standardized inoculum and incubated for 3 days at $37^{\circ} \mathrm{C}$ on a rotary shaker set at $200 \mathrm{rpm}$. Cell removal by centrifugation at $4500 \mathrm{rpm}$ $\left(45 \mathrm{~min}, 4^{\circ} \mathrm{C}\right.$ ) was done, and the supernatant was preliminarily analyzed and identified by thin-layer chromatography (TLC) for its compound.

The supernatant was mixed with absolute cold ethanol in a ratio of $1: 3(v / v)$. The reaction mixture was incubated at $-20^{\circ} \mathrm{C}$ for 24 hours. The reaction mixture was subsequently centrifuged at $4500 \mathrm{rpm}$ for $45 \mathrm{~min}$ at $4^{\circ} \mathrm{C}$ to collect the precipitate. This process was repeated until no leftover was observed from the original mixture. The pellets were dissolved in hot water followed by deproteinization by the Sevag method by adding Sevag reagent ( $\mathrm{n}$ - butanol : chloroform $=1: 5, v / v)$ to the reaction mixture and to remove denatured protein which appeared at the interface between water and chloroform layers. The procedure was repeated five times to increase yield. The supernatant was subjected to dialysis with a bag with an MWCO of $12,000 \mathrm{Da}$ against deionized water at $4^{\circ} \mathrm{C}$ for five days [47]. Consequently, deionized water was replaced with fresh water and the crude levan was obtained by lyophilization [48].

2.3.2. Fourier-Transform Infrared Spectroscopy (FTIR) Analysis. Fourier-transform infrared spectroscopy (FTIR) analysis was conducted for the determination of the func- tional group deposition of the structure of levan. The FTIR spectra were recorded in transmittance mode from the wavenumber of 4000 to $400 \mathrm{~cm}^{-1}$ on an FTIR spectrophotometer (Perkin Elmer, Frontier) at the Department of Chemistry, Faculty of Science, Burapha University, Thailand.

\subsection{3. ${ }^{1} \mathrm{H}$ and ${ }^{13} \mathrm{C}$ Nuclear Magnetic Resonance (NMR)} Spectroscopy. The levan structure was analyzed using NMR spectroscopy. Here, $0.5 \mathrm{mg}$ of levan was dissolved in $\mathrm{D}_{2} \mathrm{O}$ for each of ${ }^{1} \mathrm{H}$ NMR and ${ }^{13} \mathrm{C}$ NMR analysis. Then, the sample was submitted to Heteronuclear Single-Quantum Correlation (HSQC) analysis using $\mathrm{D}_{2} \mathrm{O}$ solvent. Spectra were recorded on Bruker UltraShield $400 \mathrm{MHz} / 54 \mathrm{~mm}$ bore. ${ }^{1} \mathrm{H}$ NMR spectra and ${ }^{13} \mathrm{C}$ NMR spectra were run at $400 \mathrm{MHz}$. (Bruker, AVANCE UltraShield $400 \mathrm{MHz}$ spectrometer) at the Department of Chemistry, Faculty of Science, Burapha University, Thailand.

\section{Results and Discussion}

3.1. Isolation and Identification of Levansucrase EnzymeProducing Bacteria. The bacteria isolated from the fermented soybean for the screening of levansucrase enzyme exhibited mucoidal colonies grown on solid medium. This colonial characteristic may be due to their production of extracellular levansucrase enzyme activities that converted sucrose present in the medium to exopolysaccharides in the form of $\beta$ $\mathrm{d}$ fructoside (levan) and glucose released. Figure 1 shows the colonies of the bacterial strains with mucoidal consistency. Thus, the bacteria exhibiting such consistency were the basis for the isolation of the bacteria for further analysis. The bacteria were subcultured onto the fresh solid medium by a standard technique. From the forty-three (43) grown colonies in the mixed culture plates, nine (9) of them exhibited discreet and mucoidal consistency. The isolates were further characterized by staining methods and found to be gram-positive, rod-shaped bacteria and have one gramnegative coccus (Table 1). The biosynthesis of levansucrase enzyme by the isolates on the selective medium containing high sucrose may be explained by the bacterial excretion mechanisms commonly observed in both gram-positive and gram-negative bacteria. Levansucrase enzyme biosynthesis in gram-positive bacteria includes enzyme accumulation into the periplasmic space and by the excretion of the enzymes out of the cell into the surrounding environment by the cleavage of a signal peptide, whereas in gramnegative bacteria, the signal peptide pathway initiates the secretion of levansucrase into the outer environment [49].

\subsection{Levansucrase Activity Assay}

3.2.1. Production of Levansucrase Enzyme from Isolates. The isolated bacterial strains selected following colony morphology and gram stain techniques were further evaluated for levansucrase enzyme production and activity. The result reveals that out of the nine bacterial strains, five strains (B-1, B-5, B-6, B-4, and B-2) showed potential for EPS production and selected for extracellular production of the enzyme (Supplementary Figure 8). The extracellular levansucrase enzyme produced by the isolates was estimated by the 


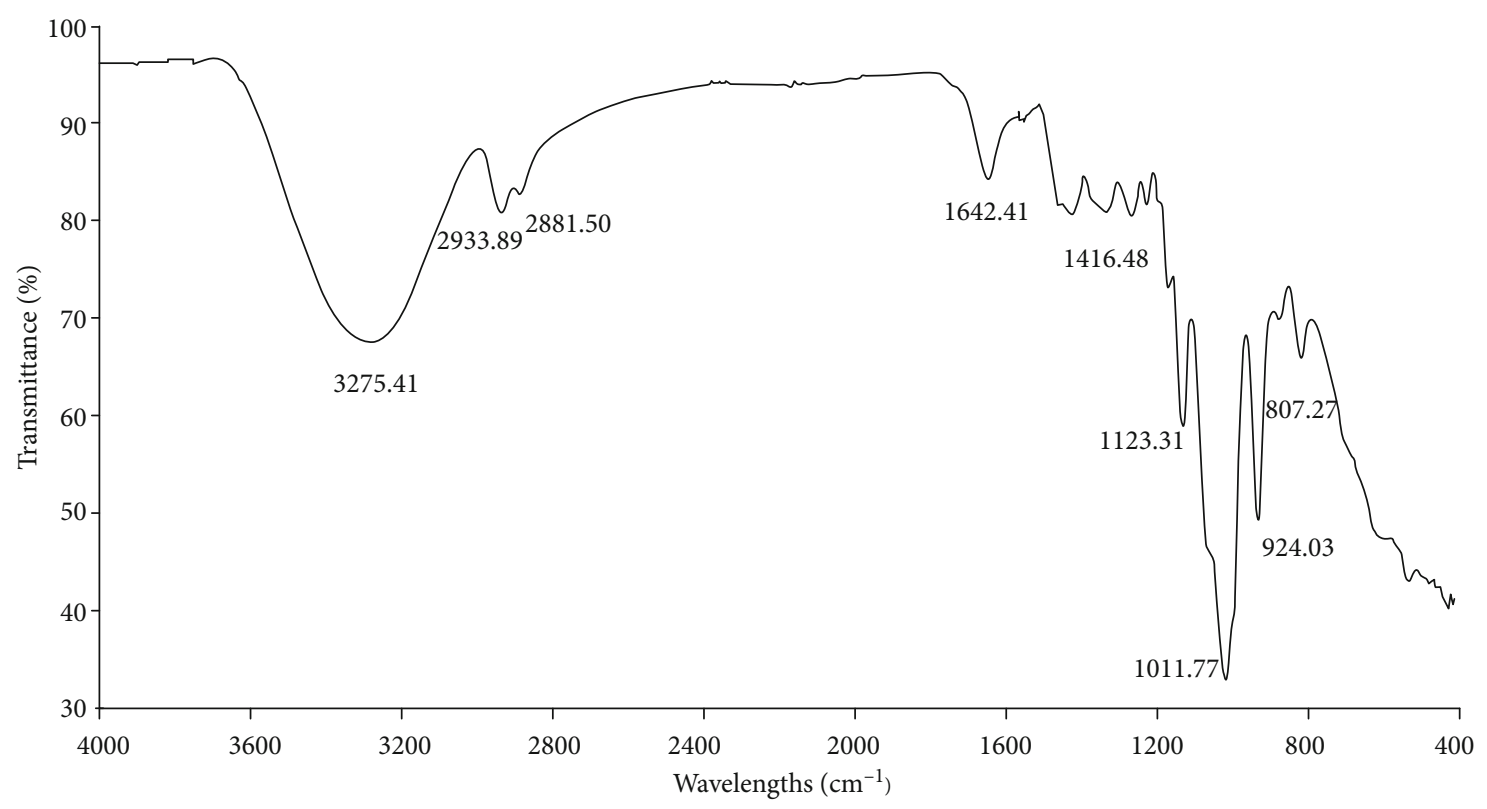

FIGURE 5: The FTIR spectrum of the produced levan from B-6 bacterial strain.

percentage efficiency of sucrose hydrolysis and calculated from the concentration of reducing sugars released (Supplementary Table 1), wherewith the mechanism of levansucrase synthesized polysaccharides and released reducing sugar from the reaction; thereby, we assume that the increasing concentration of reducing sugar is associated with high enzyme activity. Figure 2 shows the performance of the enzyme activities of the nine bacterial strains. The activity exhibited by the five strains was capable of hydrolyzing sucrose for as high as $50 \%$. On the other hand, the other four bacterial strains (B-3, B-7, B-8, and B-9) exhibited less than $59 \%$ sucrose hydrolysis. The percentage of sucrose hydrolysis of the top 5 performing enzymeproducing bacterial strains is significantly different from the enzyme activity of the four bacterial strains. Thus, isolates B-1, B-5, B-6, B-4, and B-2 were selected for further enzyme analysis. The present findings on extracellular production of enzyme by microorganism agree with the study of Maugeri and Hernalsteens [45] on the screening of the microbes obtained from the fruits and flowers that were found to secrete extracellular enzymes with high fructosyltransferase activities. The same standard medium previously described for enzyme activity consisting of $2 \%$ yeast extract, $5 \%$ sucrose, $1 \% \mathrm{NaNO}_{3}, \quad 0.01 \% \quad \mathrm{MgSO}_{4} \cdot 7 \mathrm{H}_{2} \mathrm{O}$, and $0.1 \%$ $\mathrm{K}_{2} \mathrm{HPO}_{4}$ ( $\mathrm{pH} 5.5$ ) was utilized where 495 yeast strains and 130 bacterial strains (about 25\% of the isolated strains) showed high hydrolysis activity under the sucrosecontaining medium comparable to the results presented hereof [45].

3.2.2. Enzyme Mechanisms. The five enzyme-producing bacteria were recultured for the production of extracellular enzymes in the fermented medium. Enzyme assays were determined in a reaction containing $20 \%(w / v)$ sucrose in $20 \mathrm{mM}$ sodium phosphate buffer, pH6.0, mixed with the crude enzyme. As shown in Figure 3(a), B-5, B-1, and B-6 have predominantly exhibited the highest enzyme activity of $10.30 \mathrm{IU} / \mathrm{ml}, 8.88 \mathrm{IU} / \mathrm{ml}$, and $8.51 \mathrm{IU} / \mathrm{ml}$ at $12 \mathrm{~h}$ of fermentation, respectively. Isolate $\mathrm{B}-2$ has shown the highest enzyme activity at $15 \mathrm{~h}(5.68 \mathrm{IU} / \mathrm{ml})$, and isolate $\mathrm{B}-4$ has the highest activity at $21 \mathrm{~h}(7.41 \mathrm{IU} / \mathrm{ml})$. Initially, a high concentration of sucrose in the medium activated and induced the levansucrase production and persisted at the stationary phase of growth. At this phase, the enzyme activity was gradually decreasing as the concentration of sucrose also decreased. The study of Li [20] explained that the levansucrase enzyme activity was dependent on the initial substrate concentration where the microorganisms are grown. The high concentration of substrate activates enzyme production, thus triggering the enzyme release extracellularly by the microbe. This activity was observed to be at the maximum concentration at the stationary phase of growth, following a decline of the activity at the death phase. The sucrose hydrolysis activity in the study is similar to the activity of B. amyloliquefaciens isolated from maple syrup $\left(30^{\circ} \mathrm{Bx}\right)$ at $48 \mathrm{~h}$ which resulted in the highest levansucrase activity (427.53 $\mu \mathrm{mol} / \mathrm{mg}$ protein/min) [20]. Moreover, Dajanta et al. [37] reported that during the growth phase, microbes synthesize proteolytic enzymes to digest the free amino acids present in the substrate. These findings strongly support the premise that the production of enzymes is at the maximum during the initial growth of organisms grown in high-substrate-containing medium.

3.2.3. Thin-Layer Chromatography (TLC) Analysis. After evaluating the mechanisms of the enzymes exhibited by the bacterial strains, their mixed solutions were spotted on TLC plates to determine the sugar component. Figure 3(b) shows the enzymatic reaction of all bacterial strains to hydrolyze sucrose and covert monosaccharide residue to oligosaccharides and polysaccharides. The results show that there is 


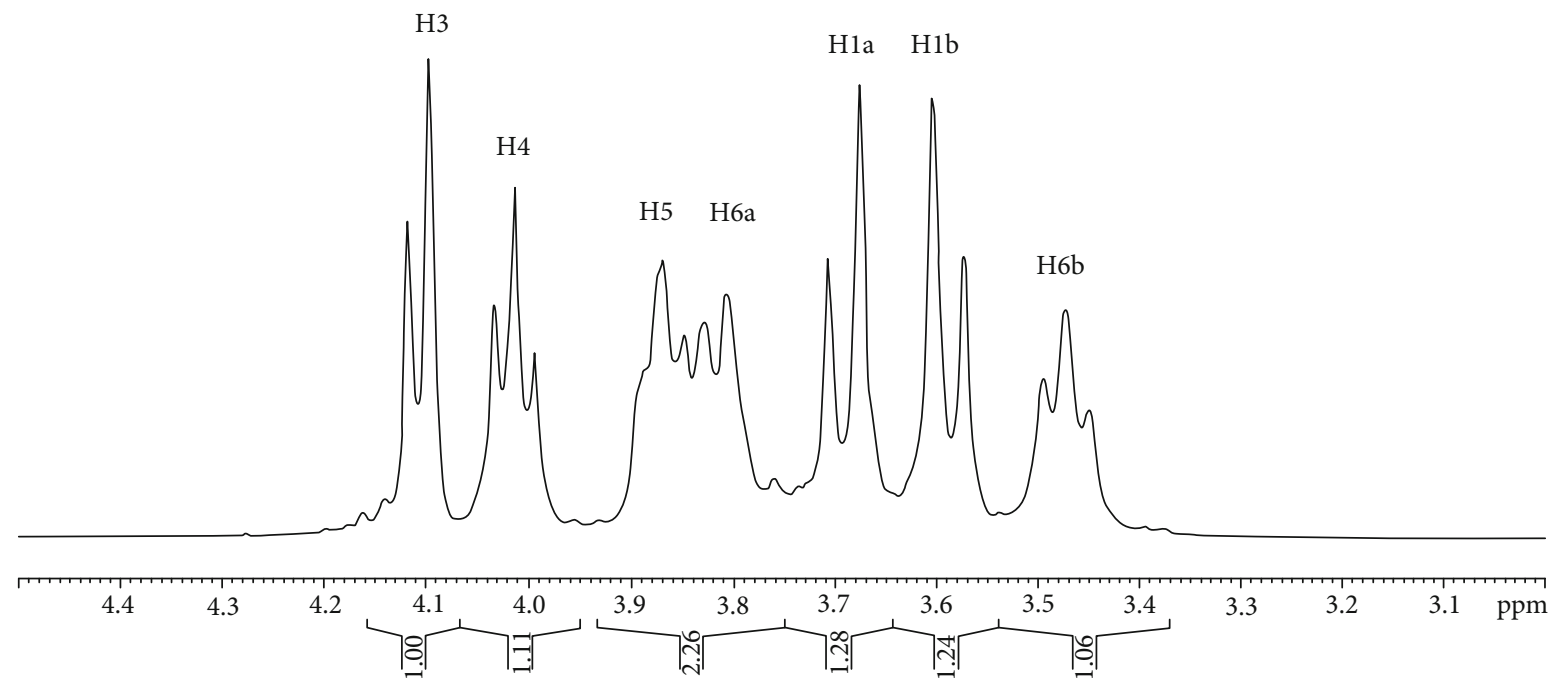

(a)

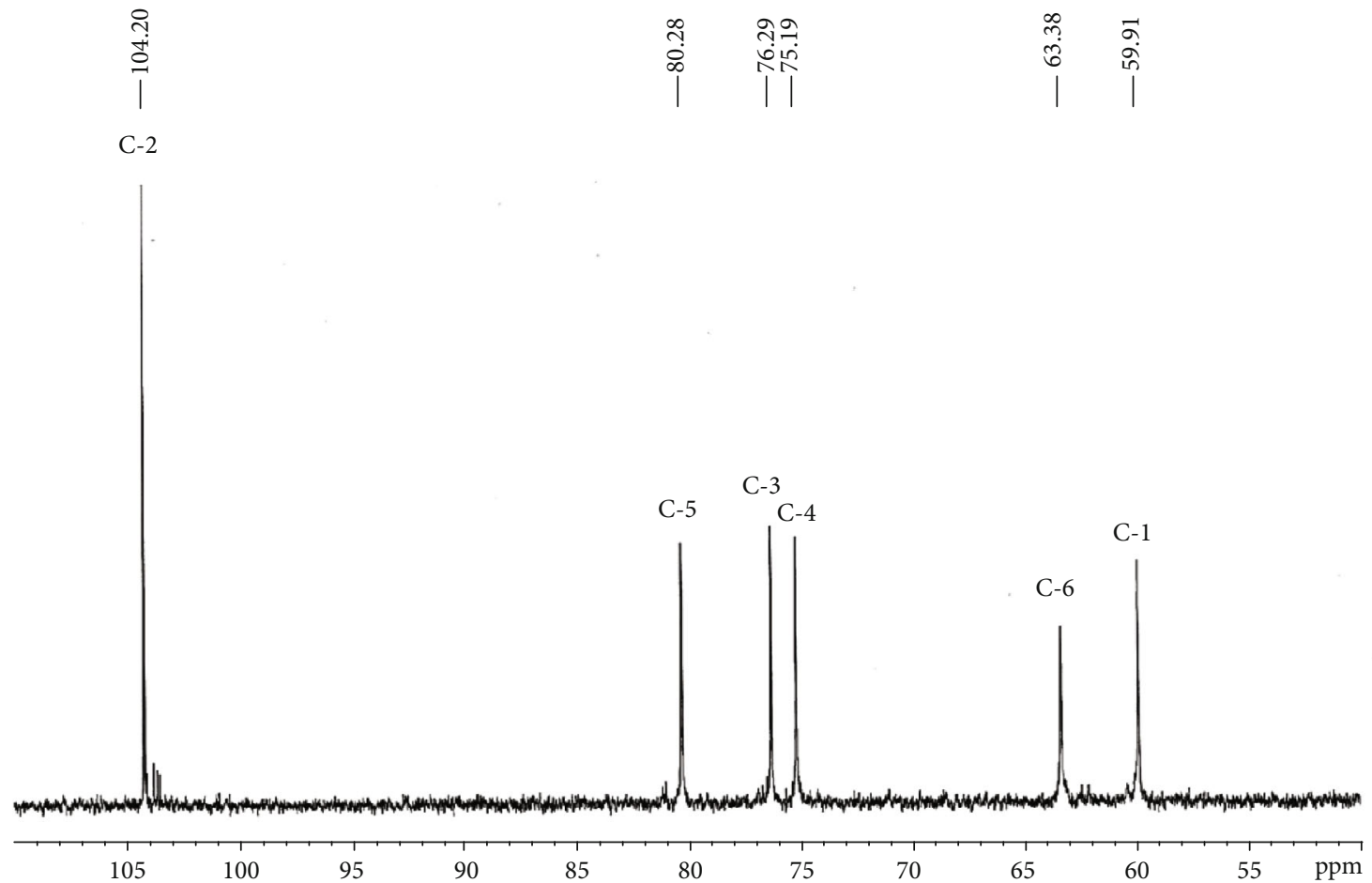

(b)

Figure 6: (a) The identification of levan produced from levansucrase of B-6 bacterial strain by ${ }^{1} \mathrm{H}$ NMR spectrum levansucrase. (b) The identification of levan produced from levansucrase of B- 6 bacterial strain by ${ }^{13} \mathrm{C}$ NMR spectrum levansucrase.

one spot of sucrose at lines 0 (at initial culturing) because the bacteria are adapting to the new environment as they divide during the lag phase. At lanes 6, 12, 24, and 48 (at 6, 12, 24, and 48 hours of culturing time) as log phase and stationary phase of cell growth progress, all bacteria grow and produce enzymes for the production of EPS. For this reason, the sugar spot at lanes $6,12,24$, and 48 revealed two parts on the TLC plate: the top part as monosaccharides and disaccharides, both of which were hydrolyzed by the extracellular enzyme, and the bottom part as EPSs that was generated from monosaccharide residues by transferase activity. TLC analysis may have limitations to distinguishing the molecular weight of 
TABLE 2: The comparison of ${ }^{13} \mathrm{C}$ chemical shift signals of levan produced by bacterial strain B-6 and by other bacteria reported elsewhere [34, 36, 41].

\begin{tabular}{|c|c|c|c|c|}
\hline \multirow[b]{2}{*}{$\begin{array}{l}\text { Carbon } \\
\text { atom }\end{array}$} & \multicolumn{4}{|c|}{ The chemical shift (ppm) of the levans formed from } \\
\hline & $B-6^{a}$ & $\begin{array}{c}B . \\
\text { megaterium } \\
\text { GJT321 [36] }\end{array}$ & $\begin{array}{c}\text { B. } \\
\text { licheniformis } \\
\text { BK AG21 [34] }\end{array}$ & $\begin{array}{c}B . \\
\text { methylotrophicus } \\
{[41]}\end{array}$ \\
\hline $\mathrm{C}-1$ & 59.91 & 59.86 & 59.81 & 61.20 \\
\hline $\mathrm{C}-2$ & 104.20 & 104.14 & 104.22 & 104.66 \\
\hline $\mathrm{C}-3$ & 76.29 & 76.25 & 76.24 & 77.51 \\
\hline $\mathrm{C}-4$ & 75.19 & 75.31 & 75.18 & 76.10 \\
\hline C-5 & 80.28 & 80.23 & 80.31 & 80.77 \\
\hline C-6 & 63.38 & 63.31 & 63.40 & 65.69 \\
\hline
\end{tabular}

${ }^{\mathrm{a}}$ Bacterial strain in this study.

polysaccharides higher than $10 \mathrm{DP}$ (degree of polymerization); thus, the extracellular enzyme catalyzed sucrose to the high molecular weight [50]. However, this method is aimed primarily at analyzing enzyme activity and at characterizing the enzymatic reaction. The EPSs produced from all the bacterial strains were isolated, and their structure was identified through the analytical methods.

\subsection{Isolation, Purification, and Identification of Levan}

3.3.1. Isolation and Purification of Levan. The EPSs produced by the extracellular enzyme from 5 bacterial strains in the fermented medium were characterized by TLC analysis using mono- and disaccharide detection (Figure 4). The results showed that the enzyme activity of the three bacterial strains, B-2, B-4, and B-6, synthesized fructans shown at a bottom spot by fructotransferase activity along with the hydrolysis activity exhibited in the spots of glucose and fructose. We compared the intensity of both spots and found that the concentration of fructose is lower than that of glucose as fructose residues were catalyzed by the fructotransferase activity into a fructan form. This activity was displayed at the lowest spots on the chromatogram as a fructan of high DP. The findings adhere with the report of Watanabe and Oda [51] on A. rouxii CBS 438.76 which hydrolyzed the FOSs, inulin, and levan into fructose, completely [51]; however, fructan production was generated by linking fructose residue of sucrose and releasing glucose, thus resulting to higher glucose concentration than fructose.

The three bacterial strains, B-2, B-4, and B-6, based on their previous enzyme activities and TLC analysis were further investigated. The enzyme activities of B- 6 bacterial strain were found to be at the highest performance at $8.51 \mathrm{IU} / \mathrm{ml}$ at $12 \mathrm{~h}$. The fructotransferase activity of B-6 bacterial strain was catalyzed to produce fructans into promising a levan form. The biosynthesis of fructan was confirmed with the cultured B-6 bacterial strain through EPS purification process. FTIR and NMR spectroscopies further characterized the product.

3.3.2. Fourier-Transform Infrared Spectroscopy (FTIR) Analysis. FTIR analysis was conducted for the determination of the functional group deposition of the structure for levan production for B- 6 bacterial strain and was recorded in transmittance mode from the wavenumber of 4,000 to $400 \mathrm{~cm}^{-1}$ and was compared to the standard levan (Supplementary Figures 6-7). Figure 5 presents a broad and strong peak at $3600-3200 \mathrm{~cm}^{-1}$ (specifically, at $3275.41 \mathrm{~cm}^{-1}$ ) as $\mathrm{O}-\mathrm{H}$ stretching vibration due to intermolecular hydrogen bonding [52]. C-H stretching vibration appears at 3,000$2,800 \mathrm{~cm}^{-1}$ (specifically, at 2933.89 and $2881.50 \mathrm{~cm}^{-1}$ ). The broad peak at $2933.89 \mathrm{~cm}^{-1}$ is the methylene group that vibrated asymmetrically, but the broad peak at $2881.50 \mathrm{~cm}^{-1}$ vibrates symmetrically. $\mathrm{C}-\mathrm{H}$ bending vibration of the methylene group appears at $1416.48 \mathrm{~cm}^{-1}$ [53]. A broad band at $1642.41 \mathrm{~cm}^{-1}$ was due to the bound water [54]. C$\mathrm{O}-\mathrm{H}$ stretching vibration appears at $1123.31 \mathrm{~cm}^{-1}$, and the strong broad peak at $1011.77 \mathrm{~cm}^{-1}$ was characterized by glycosidic linkage (C-O-C) stretching vibration in pyranose or furanose which is the carbohydrate fingerprint $[55,56]$. The broad peak at 924.03 and $807.27 \mathrm{~cm}^{-1}$ is confirmed as the furanose of the sugar units [57]. The spectra show two broad peaks at 917 and $770 \mathrm{~cm}^{-1}$, characteristic of several pyranoses [58]. The resulting spectrum represents the molecular absorption and transmission, creating a molecular fingerprint of polysaccharide. These values are almost identical to the previous report on the values of levan produced by Brenneria goodwinii [48].

3.3.3. Analysis of ${ }^{1} \mathrm{H},{ }^{13} \mathrm{C} \mathrm{NMR}$, and $2 \mathrm{D}$ Heterocorrelated HSQC Spectra. ${ }^{1} \mathrm{H}$ and ${ }^{13} \mathrm{C}$ NMR spectroscopy provides complementary data regarding the levan structure. The ${ }^{1} \mathrm{H}$ NMR spectra (Figure 6(a)) were also observed for the proton chemical shift signal related to the fructose as a monomer of levan. This signal which was present at the chemical shift of $4.098 \mathrm{ppm} \quad(\mathrm{H} 3), \quad 4.014 \mathrm{ppm} \quad(\mathrm{H} 4), \quad 3.867 \mathrm{ppm} \quad(\mathrm{H} 5)$, $3.828 \mathrm{ppm}$ (H6a), $3.673 \mathrm{ppm}$ (H1a), $3.604 \mathrm{ppm}$ (H1b), and $3.48 \mathrm{ppm}(\mathrm{H} 6 \mathrm{~b})$ (shown in Supplementary Figures 2-4) corresponded to the levan product resonance of $B$. megaterium GJT321 [55], B. methylotrophicus SK 21.002 [47], and B. licheniformis BK AG21 [53].

The ${ }^{13} \mathrm{C}$ spectrum (Figure $6(\mathrm{~b})$ ) showed six resonance signals, $104.02 \mathrm{ppm}(\mathrm{C} 2), 80.28 \mathrm{ppm}$ (C5), $76.29 \mathrm{ppm}$ (C3), $75.19 \mathrm{ppm}$ (C4), $63.38 \mathrm{ppm}$ (C6), and $59.91 \mathrm{ppm} \mathrm{(C1)}$ (shown in Supplementary Figure 5), which confirmed hexose shape of the monosaccharides of EPS and are related closely to levan since these were identified by the carbon chemical shift of levan that has been reported from the previous studies (Table 2).

Additionally, the six signals displayed from ${ }^{13} \mathrm{C}$ NMR spectral analysis correspond to the fructose residue. The anomeric carbon atom (C2) was shown at $104.02 \mathrm{ppm}$ while $\mathrm{C} 1$ and C6 of the methylene group was shown at 59.91 and $63.38 \mathrm{ppm}$, respectively. The peak signal at $80.28 \mathrm{ppm}$ was attributed to furanose (C2), whereas the peaks at 76.29 and 75.19 of $\mathrm{C} 3$ and $\mathrm{C} 4$, respectively, correlated to oxymethinic groups.

Furthermore, the HSQC analysis was performed to investigate hydrogen atoms linked to their respective carbon atoms. The obtained spectra displayed the corresponding cross-peaks between $\mathrm{H} 1 \mathrm{a} / \mathrm{C} 1, \mathrm{H} 1 \mathrm{~b} / \mathrm{C} 1, \mathrm{H} 3 / \mathrm{C} 3, \mathrm{H} 4 / \mathrm{C} 4, \mathrm{H} 5 / \mathrm{C} 5, \mathrm{H} 6 \mathrm{a} / \mathrm{C} 6$, and H6b/C6. However, no cross-peaks at $\mathrm{C} 2$ were observed (Table 3). The results affirmed the quaternary anomeric 
TABLE 3: The HSQC chemical shifts signals in $\mathrm{D}_{2} \mathrm{O}$ of the fructose residue of levan product from B-6 bacterial strain.

\begin{tabular}{|c|c|c|c|c|c|c|c|c|}
\hline \multirow[b]{2}{*}{ Atoms } & \multicolumn{8}{|c|}{ The chemical shift (ppm) } \\
\hline & $\mathrm{H} 1 \mathrm{a} / \mathrm{C} 1$ & $\mathrm{H} 1 \mathrm{~b} / \mathrm{C} 1$ & $\mathrm{C} 2$ & $\mathrm{H} 3 / \mathrm{C} 3$ & $\mathrm{H} 4 / \mathrm{C} 4$ & $\mathrm{H} 5 / \mathrm{C} 5$ & $\mathrm{H} 6 \mathrm{a} / \mathrm{C} 6$ & $\mathrm{H} 6 \mathrm{~b} / \mathrm{C} 6$ \\
\hline${ }^{1} \mathrm{H}$ & 3.61 & 3.72 & - & 4.11 & 4.05 & 3.87 & 3.82 & 3.52 \\
\hline${ }^{13} \mathrm{C}$ & 60.0 & 60.0 & 104 & 76.2 & 74.1 & 79.0 & 63.0 & 63.0 \\
\hline
\end{tabular}

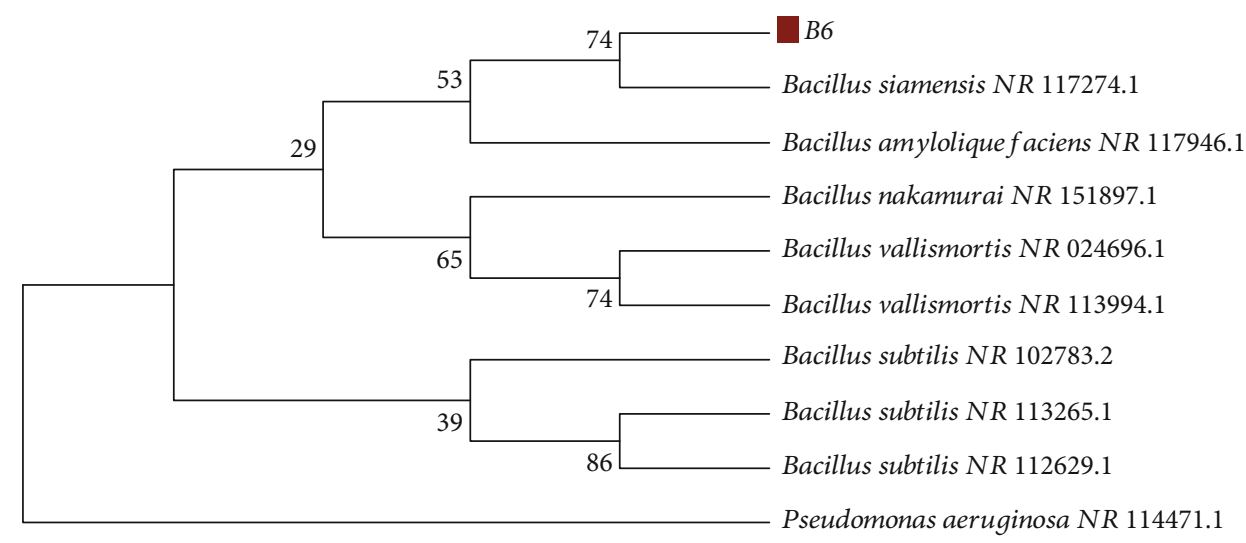

FIGURE 7: Neighbor-joining tree constructed in comparison with the 16s rDNA gene sequences of the isolated levansucrase-producing bacteria with sequences available in GenBank. Bacterial strain B-6 has high similarity with B. siamensis NR 11274.1. P. aeruginosa NR 114471.1, a gram-negative bacterium, was used as an outgroup.

carbon character (C2). This evidence shows that the signals from the ${ }^{1} \mathrm{H},{ }^{13} \mathrm{C} \mathrm{NMR}$, and the HSQC refer to the characteristics of $\beta$ - $(2,6)$ linkages of the fructose residue of the levan product from levansucrase of the B-6 bacterial strain.

3.4. Bacterial Identification. Based on the overall activity of all the enzyme-producing bacteria isolated in this work, the B-6 bacterial strain was the main interest for its highest levansucrase enzyme production for the synthesis of levan. The morphological characteristics of the colony of the isolate were large, round, transparent colonies, with a smooth surface. Microscopically, the isolate appeared as grampositive and rod-shaped. Based on the molecular analysis of the strains, 16s rDNA gene sequences demonstrated the highest percent similarity of $99.68 \%$ with $B$. siamensis NR_ 117274.1 (a partial sequence comprising 1,525 bp) available in GenBank. Figure 7 shows the neighbor-joining tree constructed with the gene sequence of the strain of interest with those sequence results from the BLAST database. The BLAST results were utilized for the molecular identification of levansucrase enzyme-producing bacteria in the study. A similar study reported the isolation of gram-positive, rod-shaped levansucrase enzyme-producing microorganism with identity belonging to $B$. methylotrophicus based on the $16 \mathrm{~s}$ rDNA gene sequences analysis [47].

\section{Conclusions}

The results from this study demonstrated the presence of levansucrase enzyme-producing bacteria isolated from the traditional Thai fermented food and their potential application for production of the prebiotic levan. The screening and isola- tion procedures for extracellular levansucrase activity resulted in five bacterial strains (B-1, B-2, B-4, B-5, and B-6) exhibiting varying sucrose hydrolyzing activities. Isolates B-5, B-1, and B6 showed the highest total activity at 12 hours at $20.60,17.16$, and $8.51 \mathrm{UI} / \mathrm{ml}$, respectively. Overall, bacterial strain B-6 had the highest fructosytransferase activity for producing fructan. Based on the FTIR, NMR, and HSQC analyses, the structure for the fructan was a levan consisting of consecutive $\beta-(2,6)$ fructopyranose units. Based on the morphological and molecular identification, 16s rDNA gene sequence analysis confirmed the identity of the bacterial strain as B. siamensis NR 11274.1. Factors such as varying temperatures, agitations, incubation time, carbon sources, and the use of other culture media may be explored further to determine their influence in the levansucrase enzyme production of the isolates.

\section{Data Availability}

The data used to support the findings of this study are included within the supplementary information file(s).

\section{Conflicts of Interest}

The authors declare that they have no conflicts of interest.

\section{Acknowledgments}

This work was supported by the National Research Council of Thailand (grant number 19/2561). 


\section{Supplementary Materials}

Supplementary Figure 1: the 16s rDNA sequencing analysis results revealing the identity of levansucrase-producing bacterial isolate B-6 as Bacillus siamensis NR 11274.1 based on the percent (\%) similarity score of 100 . The results have been generated by the Thailand Institute of Scientific and Technological Research, Biodiversity Research Center, March 2, 2018. Supplementary Figure 2: the 2D NMR testing results of the levan product produced by strain B-6. The HSQC spectrum in $\mathrm{D}_{2} \mathrm{O}$ of the levan product from levansucrase of B-6 bacterial strain displays the direct connectivity between ${ }^{13} \mathrm{C}$ and ${ }^{1} \mathrm{H}\left(J_{\mathrm{H} / \mathrm{C}}\right)$ of the fructose residue of levan ( ${ }^{\text {st }}$ time). Supplementary Figure 3: the HSQC spectrum in $\mathrm{D}_{2} \mathrm{O}$ of the levan product from levansucrase of B-6 bacterial strain displays the direct connectivity between ${ }^{13} \mathrm{C}$ and ${ }^{1} \mathrm{H}\left(J_{\mathrm{H} / \mathrm{C}}\right)$ of the fructose residue of levan ( $2^{\text {nd }}$ time). Supplementary Figure 4: the HSQC spectrum in $\mathrm{D}_{2} \mathrm{O}$ of the levan product from levansucrase of B-6 bacterial strain displays the direct connectivity between ${ }^{13} \mathrm{C}$ and ${ }^{1} \mathrm{H}\left(J_{\mathrm{H} / \mathrm{C}}\right)$ of the fructose residue of levan ( $3^{\text {rd }}$ time). Supplementary Figure 5: the identification of levan produced from levansucrase of B-6 bacterial strain by ${ }^{13} \mathrm{C}$ NMR spectrum levansucrase. Supplementary Figure 6: the FTIR spectra of the reference standard levan. Supplementary Figure 7: the FTIR spectra of the levan produced by the bacterial strain, B-6. Supplementary Figure 8: results of the relative nine bacterial strains isolated from fermented soybean. The relative activity refers to the maximum activity. Isolates B-3, B-7, B-8, and B-9 are statistically different with B-1. Supplementary Figure 9: sucrose-hydrolyzing activity analysis of the extracellular enzyme produced by the five bacterial strains. Supplementary Table 1: DNS assay spectrophotometer readings of the relative sucrose hydrolysis of the nine bacterial strains isolated from fermented soybean. Supplementary Table 2: determination of the enzyme activity concentration of reducing sugar by the DNS method. (Supplementary Materials)

\section{References}

[1] I. W. Sutherland, "Novel and established applications of microbial polysaccharides," Trends in Biotechnology, vol. 16, no. 1, pp. 41-46, 1998.

[2] A. S. Kumar, K. Mody, and B. Jha, "Bacterial exopolysaccharides-a perception," Journal of Basic Microbiology, vol. 47, no. 2, pp. 103-117, 2007.

[3] E. Rosenberg and E. Z. Ron, "Bioemulsans: microbial polymeric emulsifiers," Current Opinion in Biotechnology, vol. 8, no. 3, pp. 313-316, 1997.

[4] C. C. Lin and L. E. Casida Jr., "GELRITE as a gelling agent in media for the growth of thermophilic microorganisms," Applied and Environmental Microbiology, vol. 47, no. 2, pp. 427-429, 1984.

[5] V. Ripari, "Techno-functional role of exopolysaccharides in cereal-based, yogurt-like beverages," Beverages, vol. 5, no. 1, p. 16, 2019.

[6] P. Ruas-Madiedo, J. A. Moreno, N. Salazar et al., "Screening of exopolysaccharide-producing Lactobacillus and Bifidobacterium strains isolated from the human intestinal microbiota,"
Applied and Environmental Microbiology, vol. 73, no. 13, pp. 4385-4388, 2007.

[7] P. Jiang, J. Li, F. Han et al., "Antibiofilm activity of an exopolysaccharide from marine bacterium Vibrio sp. QY101," PLoS One, vol. 6, no. 4, 2011.

[8] A. Pérez-Ramos, M. Nácher-Vázquez, S. Notararigo, P. López, and M. L. Mohedano, Current and future applications of bacterial extracellular polysaccharides, pp. 329-344, Elsevier, Oxford, UK, 2015.

[9] M. Pineiro, N. G. Asp, G. Reid et al., "FAO technical meeting on prebiotics," Journal of Clinical Gastroenterology, vol. 42, pp. S156-S159, 2008.

[10] M. B. Roberfroid, "Prebiotics," in Encyclopedia of Food Sciences and Nutrition, B. Caballero, Ed., pp. 4719-4723, Academic Press, Oxford, Second edition, 2003.

[11] D. Davani-Davari, M. Negahdaripour, I. Karimzadeh et al., "Prebiotics: definition, types, sources, mechanisms, and clinical applications,” Foods, vol. 8, no. 3, p. 92, 2019.

[12] J. Gu and K. Roberts, "Chapter 6 - probiotics and prebiotics," in Adult Short Bowel Syndrome, M. L. Corrigan, K. Roberts, and E. Steiger, Eds., pp. 67-80, Academic Press, 2019.

[13] E. Pessione, "Lactic acid bacteria contribution to gut microbiota complexity: lights and shadows," Frontiers in Cellular and Infection Microbiology, vol. 2, pp. 86-86, 2012.

[14] G. R. Gibson, A. L. McCartney, and R. A. Rastall, "Prebiotics and resistance to gastrointestinal infections," British Journal of Nutrition, vol. 93, no. S1, pp. S31-S34, 2005.

[15] A. Anadón, M. R. Martínez-Larrañaga, I. Arés, and M. A. Martínez, "Prebiotics and probiotics: An assessment of their safety and health benefits," Probiotics, prebiotics, and synbiotics: Bioactive foods in health promotion, vol. 1, 2016.

[16] G. R. Gibson and M. B. Roberfroid, "Dietary modulation of the human colonic microbiota: introducing the concept of prebiotics," The Journal of Nutrition, vol. 125, no. 6, pp. 14011412, 1995.

[17] D. de Paulo Farias, F. F. de Araújo, I. A. Neri-Numa, and G. M. Pastore, "Prebiotics: trends in food, health and technological applications," Trends in Food Science \& Technology, vol. 93, pp. 23-35, 2019.

[18] J. de Souza Aquino, K. S. Batista, F. N. D. D. Menezes, P. P. Lins, J. A. de Sousa Gomes, and L. A. da Silva, Models to evaluate the prebiotic potential of foods, Functional Food: Improve Health Through Adequate Food, 2017.

[19] A. Ashwini, H. N. Ramya, C. Ramkumar et al., "Reactive mechanism and the applications of bioactive prebiotics for human health: review," Journal of Microbiological Methods, vol. 159, pp. 128-137, 2019.

[20] M. Li, Levansucrase-Catalyzed Transfructosylation Reaction: Novel Biocatalytic Approach for the Production of Fructooligosaccharides, Oligolevans and Levans Using Maple Syrups as Reaction Media, McGill University Libraries, 2015.

[21] T. Visnapuu, K. Mardo, and T. Alamae, "Levansucrases of a Pseudomonas syringae pathovar as catalysts for the synthesis of potentially prebiotic oligo- and polysaccharides," New Biotechnology, vol. 32, no. 6, pp. 597-605, 2015.

[22] J. R. Porras-Domínguez, Á. Ávila-Fernández, M. E. RodríguezAlegría et al., "Levan-type FOS production using a Bacillus licheniformis endolevanase," Process Biochemistry, vol. 49, no. 5, pp. 783-790, 2014. 
[23] K. H. Jang, S. A. Kang, Y. H. Cho et al., "Prebiotic properties of levan in rats," Journal of Microbiology and Biotechnology, vol. 13, pp. 348-353, 2003.

[24] S.-H. Yoo, E. J. Yoon, J. Cha, and H. G. Lee, "Antitumor activity of levan polysaccharides from selected microorganisms," International Journal of Biological Macromolecules, vol. 34, no. 1-2, pp. 37-41, 2004.

[25] A. M. Abdel-Fattah, A. M. Gamal-Eldeen, W. A. Helmy, and M. A. Esawy, "Antitumor and antioxidant activities of levan and its derivative from the isolate Bacillus subtilis NRC1aza," Carbohydrate Polymers, vol. 89, no. 2, pp. 314-322, 2012.

[26] K. H. Kim, C. B. Chung, Y. H. Kim, K. S. Kim, C. S. Han, and C. H. Kim, "Cosmeceutical properties of levan produced by Zymomonas mobilis," Journal of Cosmetic Science, vol. 56, no. 6, pp. 395-406, 2005.

[27] R. Srikanth, G. Siddartha, C. H. S. S. Sundhar Reddy, B. S. Harish, M. J. Ramaiah, and K. B. Uppuluri, "Antioxidant and antiinflammatory levan produced from Acetobacter xylinum NCIM2526 and its statistical optimization," Carbohydrate Polymers, vol. 123, pp. 8-16, 2015.

[28] E. T. Oner, L. Hernandez, and J. Combie, "Review of levan polysaccharide: from a century of past experiences to future prospects," Biotechnology Advances, vol. 34, no. 5, pp. 827844, 2016.

[29] Z. Liu, Y. Jiao, Y. Wang, C. Zhou, and Z. Zhang, "Polysaccharides-based nanoparticles as drug delivery systems," Advanced Drug Delivery Reviews, vol. 60, no. 15, pp. 1650-1662, 2008.

[30] A. Tabernero, A. Gonzalez-Garcinuno, J. M. Sanchez-Alvarez, M. A. Galan, and E. M. Martin Del Valle, "Development of a nanoparticle system based on a fructose polymer: stability and drug release studies," Carbohydrate Polymers, vol. 160, pp. 26-33, 2017.

[31] P. Santos-Moriano, L. Fernandez-Arrojo, A. Poveda, J. Jimenez-Barbero, A. O. Ballesteros, and F. J. Plou, "Levan versus fructooligosaccharide synthesis using the levansucrase from Zymomonas mobilis: effect of reaction conditions," Journal of Molecular Catalysis B: Enzymatic, vol. 119, pp. 18-25, 2015.

[32] A. Szwengiel, K. Goderska, and M. Gumienna, "Synthesis of $\beta$ (2-6)-linked fructan with a partially purified levansucrase from Bacillus subtilis," Journal of Molecular Catalysis B: Enzymatic, vol. 131, pp. 1-9, 2016.

[33] Y. W. Han, "Microbial Levan," Advances in Applied Microbiology, vol. 35, pp. 171-194, 1990.

[34] B. L. Cantarel, P. M. Coutinho, C. Rancurel, T. Bernard, V. Lombard, and B. Henrissat, "The Carbohydrate-Active EnZymes database (CAZy): an expert resource for glycogenomics," Nucleic Acids Research, vol. 37, no. Database, pp. D233-D238, 2009.

[35] M. A. Anwar, H. Leemhuis, T. Pijning, S. Kralj, B. W. Dijkstra, and L. Dijkhuizen, "The role of conserved inulosucrase residues in the reaction and product specificity of Lactobacillus reuteri inulosucrase," The FEBS Journal, vol. 279, no. 19, pp. 3612-3621, 2012.

[36] I.-L. Shih and Y.-T. Yu, "Simultaneous and selective production of Levan and poly(?-glutamic acid) by Bacillus subtilis," Biotechnology Letters, vol. 27, no. 2, pp. 103-106, 2005.

[37] K. Dajanta, A. Apichartsrangkoon, E. Chukeatirote, and R. A. Frazier, "Free-amino acid profiles of thua nao, a Thai fermented soybean," Food Chemistry, vol. 125, no. 2, pp. 342-347, 2011.
[38] J. W. B. A. T. MITTWER, "The Gram stain," Bacteriological Reviews, vol. 16, no. 1, pp. 1-29, 1952.

[39] J. Marmur, "A procedure for the isolation of deoxyribonucleic acid from micro-organisms," Journal of Molecular Biology, vol. 3, no. 2, pp. 208-IN1, 1961.

[40] P. Yukphan, W. Potacharoen, S. Tanasupawat, M. Tanticharoen, and Y. Yamada, "Asaia krungthepensis sp. nov., an acetic acid bacterium in the $\alpha$-Proteobacteria," International Journal of Systematic and Evolutionary Microbiology, vol. 54, no. 2, pp. 313-316, 2004.

[41] J. D. Thompson, T. J. Gibson, F. Plewniak, F. Jeanmougin, and D. G. Higgins, "The CLUSTAL_X windows interface: flexible strategies for multiple sequence alignment aided by quality analysis tools," Nucleic Acids Research, vol. 25, no. 24, pp. 4876-4882, 1997.

[42] M. Kimura, "A simple method for estimating evolutionary rates of base substitutions through comparative studies of nucleotide sequences," Journal of Molecular Evolution, vol. 16, no. 2, pp. 111-120, 1980.

[43] K. S. Belghith, I. Dahech, H. Belghith, and H. Mejdoub, "Microbial production of levansucrase for synthesis of fructooligosaccharides and levan," International Journal of Biological Macromolecules, vol. 50, no. 2, pp. 451-458, 2012.

[44] A. A. N. Saqib and P. J. Whitney, "Differential behaviour of the dinitrosalicylic acid (DNS) reagent towards mono- and disaccharide sugars," Biomass and Bioenergy, vol. 35, no. 11, pp. 4748-4750, 2011.

[45] F. Maugeri and S. Hernalsteens, "Screening of yeast strains for transfructosylating activity," Journal of Molecular Catalysis B: Enzymatic, vol. 49, no. 1-4, pp. 43-49, 2007.

[46] I. Dahech, H. B. Ayed, K. S. Belghith, H. Belghith, and H. Mejdoub, "Microbial production of levanase for specific hydrolysis of levan," International Journal of Biological Macromolecules, vol. 60, pp. 128-133, 2013.

[47] T. Zhang, R. Li, H. Qian, W. Mu, M. Miao, and B. Jiang, "Biosynthesis of levan by levansucrase from Bacillus methylotrophicus SK 21.002," Carbohydrate Polymers, vol. 101, pp. 975981, 2014.

[48] Q. Liu, S. Yu, T. Zhang, B. Jiang, and W. Mu, "Efficient biosynthesis of levan from sucrose by a novel levansucrase from Brenneria goodwinii," Carbohydrate Polymers, vol. 157, pp. 1732-1740, 2017.

[49] R. Srikanth, C. H. Reddy, G. Siddartha, M. J. Ramaiah, and K. B. Uppuluri, "Review on production, characterization and applications of microbial levan," Carbohydrate Polymers, vol. 120, pp. 102-114, 2015.

[50] N. Benkeblia, "Fructooligosaccharides and fructans analysis in plants and food crops," Journal of Chromatography A, vol. 1313, pp. 54-61, 2013.

[51] T. Watanabe and Y. Oda, "Comparison of sucrosehydrolyzing enzymes produced by Rhizopus oryzae and Amylomyces rouxii," Bioscience, Biotechnology, and Biochemistry, vol. 72, no. 12, pp. 3167-3173, 2014.

[52] M. S. Bostan, E. C. Mutlu, H. Kazak, S. Sinan Keskin, E. T. Oner, and M. S. Eroglu, "Comprehensive characterization of chitosan/PEO/levan ternary blend films," Carbohydrate Polymers, vol. 102, pp. 993-1000, 2014.

[53] D. Wahyuningrum and R. Hertadi, "Isolation and characterization of levan from moderate halophilic bacteria Bacillus licheniformis BK AG21," Procedia Chemistry, vol. 16, pp. 292-298, 2015. 
[54] S. Ramamoorthy, A. Gnanakan, S. S. Lakshmana, M. Meivelu, and A. Jeganathan, "Structural characterization and anticancer activity of extracellular polysaccharides from ascidian symbiotic bacterium Bacillus thuringiensis," Carbohydrate Polymers, vol. 190, pp. 113-120, 2018.

[55] X. Yu, L. Li, J. Zhang et al., "Structural analysis of macromolecular levan produced by Bacillus megaterium GJT321 based on enzymatic method," International Journal of Biological Macromolecules, vol. 93, pp. 1080-1089, 2016.

[56] H. Kazak Sarilmiser, O. Ates, G. Ozdemir, K. Y. Arga, and E. Toksoy Oner, "Effective stimulating factors for microbial levan production by Halomonas smyrnensis AAD6T," Journal of Bioscience and Bioengineering, vol. 119, no. 4, pp. 455-463, 2015.

[57] D. Ni, W. Xu, Y. Bai, W. Zhang, T. Zhang, and W. Mu, "Biosynthesis of levan from sucrose using a thermostable levansucrase from Lactobacillus reuteri LTH5448," International Journal of Biological Macromolecules, vol. 113, pp. 29-37, 2018.

[58] Q. Zhou, F. Feng, Y. Yang et al., "Characterization of a dextran produced by Leuconostoc pseudomesenteroides XG5 from homemade wine," International Journal of Biological Macromolecules, vol. 107, pp. 2234-2241, 2018. 